Document downloaded from:

http://hdl.handle.net/10251/34924

This paper must be cited as:

Lloret Romero, MN. (2011). The management of e-book collections and their implication on the economic management of the library. Bottom Line: Managing Library Finances. 24(3):173-179. doi:10.1108/08880451111186017.

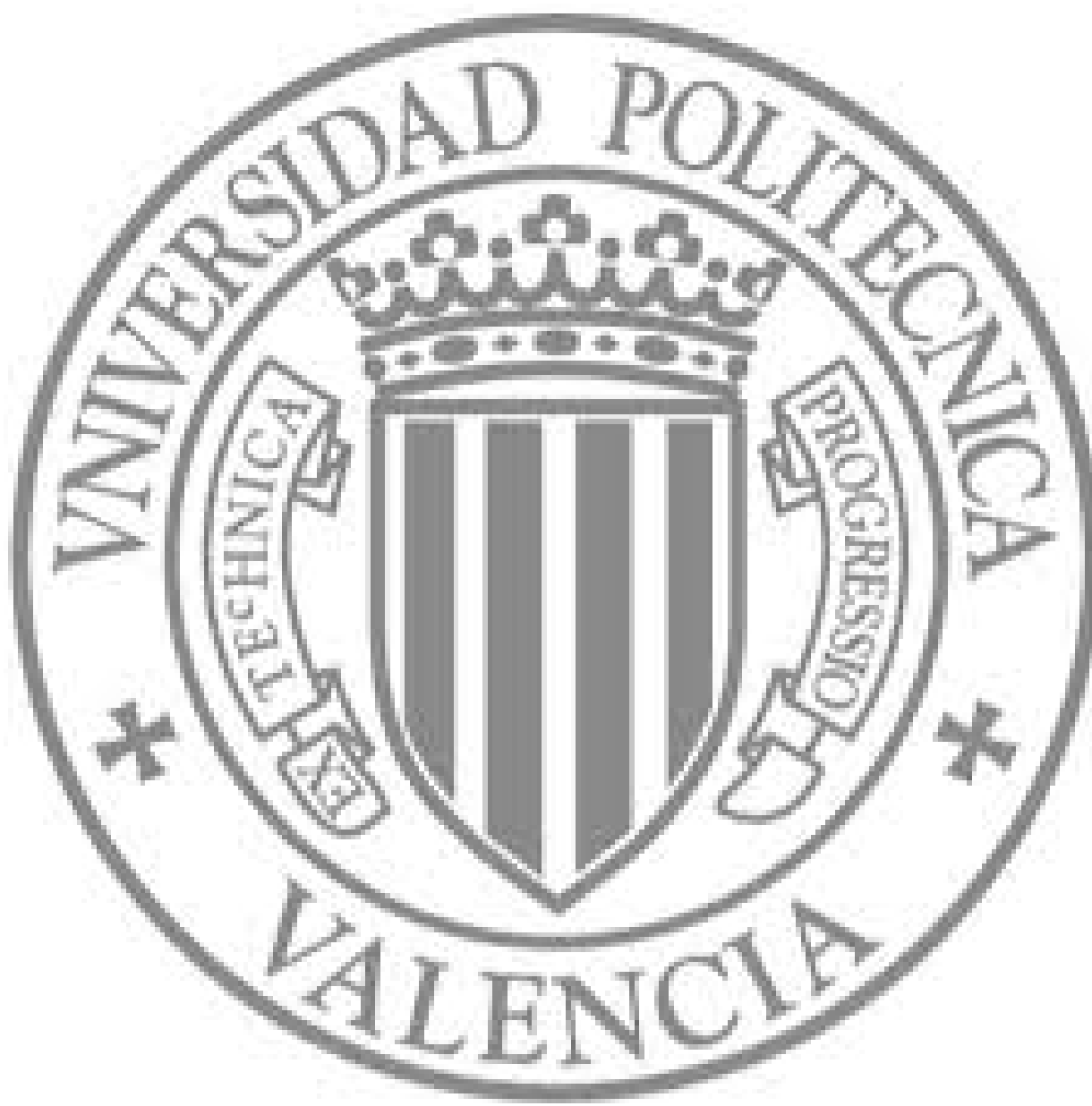

The final publication is available at

http://dx.doi.org/10.1108/08880451111186017

Copyright Emerald 


\title{
The management of e-book collections and their implication on the economic management of the library
}

\author{
Nuria Lloret Romero \\ Polytechnic University of Valencia \\ DCADHA \\ Valencia - SPAIN \\ Email: nlloret@upvnet.upv.es
}

\begin{abstract}
Purpose: The addition of digital formats such as specialised magazines and e-books to libraries, has led to a dramatic change in management format with respect to those involved in the reading process: users, publishers, distributors, booksellers, and authors; and in turn, the way in which libraries are planned and managed.
\end{abstract}

Design/methodology/approach: The article makes an analysis on the implementation of e-book and way to influence the economic management of the institution for it has been analyzed

relevant literature on the implementation of electronic books not only in the library field but in other sectors, the article uses various sources to offer conclusions on the interest not only economic but also to improve quality of service offered to its implementation in libraries or centers documentation. 
Findings: Not only is there space-saving in libraries but also a new manner in which to consume information that libraries must adapt to as soon as possible given the increasing demands of users in this connection. All of the above has given rise to changes in the economic management of libraries.

Originality/value: These changes must be assessed before making a decision regarding the purchase of e-book collections and their subsequent organization and management, which indirectly change many of the tasks currently carried out by library staff members, thereby optimizing times and processes for the benefit of increased visibility of the electronic collection.

Keywords: libraries, e-books, financial management

Paper type: General review

Accepted: $15^{\text {th }}$ July 2011

\section{From specialised journals in digital format to e-books}

E-books represent the second stage in the evolution of the digital revolution. Their presence in libraries and the users' knowledge level is still low, but the development of specific collections by publishers, advances in on-line distribution systems and improvements in e- readers are changing this situation, which in turn will have important consequences for the production and consumption of such materials beyond those of a purely technological nature. Whereas a clear change in the use of scientific information was evidenced as a result of the launching of scientific journals, in the case of e-books, an even greater change is being evidenced given the large majority of users encompassed. Furthermore, while electronic information was exclusively for the specialised users in each sector, e-books reach any user of any discipline, and especially the end consumer, extending to leisure spaces, schools, etc, since the entire population is a potential user of this type of devices. Scientific journals are now an established and irreversible model of the incorporation of electronic publishing in the processes of scientific communication, especially in research libraries. However, the response to digital books has been mixed, taking into consideration that they were introduced in libraries in the same years as journals, but with a lower level of acceptance by users. This 
reaction was due, inter alia, to the lack of specific reading devices allowing documents with a large number of pages to be read comfortably as in the case of books.

Seen in this light, the first question that needs to be asked are as follows: in what key ways should the manner in which collections are managed be changed in order to be efficient and reduce costs to the potential user of such digital products?

The general advantages arising are as follows:

-Multiple access is allowed.

-Continuous access at any time and place.

-Instant delivery.

-Saving of shelf space.

-Prevention from damage, loss or theft.

-No shipping and handling.

-Access to out of print materials.

However, there are some drawbacks:

-Cost of e-book readers.

-Difficulty in accessing computers or the Internet.

-Resistance to change in reading habits.

-Lack of knowledge of software / hardware.

Moving directly to the focus of this article on the changing of work processes in the library relating to the management of e-book collections, the integration of e-books in the library primarily has implications for three areas of processes and services:

- Purchasing Service

- Organization planning service

- Collection circulation service

\section{Purchases}

Experience in the management of electronic resources acquired by librarians over a decade ago is relevant in many respects to meet the new challenge of incorporating ebooks in libraries. The business model for the acquisition of e-books is in a defining 
stage with proposals such as establishing a higher price for libraries to offset possible losses on the sales no longer made. Although the price of a printed book is the same for both consumers and libraries, the arrival of e-books has led to a change, since libraries are required to pay more for books given the multiple use of this resource.

Another model proposes the purchase of a copy, followed by the payment of a license fee every time someone downloads it, prints, etc. Generally, business models hover between the plurality of access provided by new technologies and proposed restrictions on same publishers to safeguard their interests. In e-book marketing models, specific aspects respond to idiosyncrasies of the monograph and the publishers' caution against the risk of this format to their business.

-Package selection or Pick and Choose. Publishers generally allow both options. Package purchases prevent librarians from having to make a selection, although there will be high demand for some of the titles while others will scarcely be consulted due to the imbalance of the selection, with titles of high interest to users and others of only relative interest. The package license option is cheaper in terms of total titles than individual stock selection, but the latter ensures that the titles selected are more relevant.

-Access License and purchases in perpetuity. Publishers also offer buyers the opportunity to buy books in perpetuity, or purchase an access license which is renewable on an annual basis. Each option has advantages and drawbacks: the first of which is price, given that a permanent copy is always more expensive, although the same book will not be paid for repeatedly each year. However, the license option also enables the collection to be continually renewed.

-Publisher versus aggregator - One of the most controversial aspects of e-book marketing is the immediacy of the relationship between the publisher and user, which could affect other agents until now required in the marketing of books such as booksellers and distributors. These agents are likely to be replaced by the publisher directly, or by a marketing platform such as Amazon, Barnes \& Noble, or in Spain, Libranda, TodoeBooks, Leer-E and Luarna, which sell e-books from several publishers. Single-use versus multi-user access. One of the advantages of digital formats as compared to print books is the multiple use of the document by several people at the same time. In the case of single use, books are lent as if they were a physical unit, in the same manner as the hard copy of a document, i.e. for use by one reader at one time. This is possible through the use of a DRM (Digital Rights Management) device, but it also 


\section{Planning and organisation service}

Two ways of organising electronic books in libraries are under consideration: the integration of these materials in libraries' OPAC, or their consultation from the publishers' platforms. The advantage of the aggregators' platforms is that they will enable users to search for both books and journal or magazine articles, or to search for each separately. Moreover, integration in the library catalog facilitates queries when searching for monographic material, as some providers also provide the e-book MARC record free. However, the use of both is not incompatible. In terms of organization it must be taken into account that users who are already familiar with internet access will want to locate information in a basic google search style, as in the case of more specialised OPAC. Therefore, it is important to have a good metadata description so the user is able to find the titles in any more general way than just by subject matter, etc. This will involve extra work in relation to the description and classification of books. The time required to organize the print library books purchased will be converted in time spent on best describing the materials for their access by end users. The change in professional profile was already implicit from the time that Internet use became widespread but the current globalization of the use of electronic resources requires professionals to manage all of their time with these activities in mind.

\section{Collection circulation}

The implementation of this new service will require a promotion plan through different channels. The desire of library managers is for their investment in the implementation of this new content to be reflected in usage statistics. Additionally, the budget should be optimized. 
E-book lending in a strict sense involves the e-books inclusion in the catalog or on a specific platform. In public libraries the tendency is to use platforms integrated into the libraries' web, which allow for the design and structure of the institutions' image to be customised. In the U.S. the leading company is Overdrive, which is most famous for its use by the New York Public Library (NYPL), which has approximately 18,300 electronic titles, which when compared to its collection of printed books, amounting to 860,500 titles, accounts for only $2 \%$ of the total. However, the advent of new formats is having a significant effect in terms of the number of books borrowed, which in just a couple of years has increased from 607,275 borrowed in 2007 to almost one million in 2009.

A visit to the library is not even required for the purpose of loaning materials, but rather a visit to the website from home or any other location, the only requirements being that the user is a library member and that he provides the proper identification data in order to be able to download books to his computer or device. The downloaded book has the DRM system built-in, which automatically makes the book disappear from one's device once the loan period has been completed, meaning that it is not even necessary to return the book, and consequently there will be no fines for late returns. According to preliminary data, the use of such platforms has resulted in an increase in the number of loans. However, the problem is that there is a loss of the visitors and consequently, the loss of the library as a meeting space.

There are also additional advantages such as the fact that this is a permanent service which is available 24 hours a day, no books are lost due to theft, and the books do not become deteriorated. Therefore, there is no need to replace them and there are no expenses relating to their repair. Despite these obvious advantages there are some problems which have yet to be satisfactorily resolved, such as the fact that DRM e-books limit many of the possibilities offered by the digital format such as multiuser access, i.e. books are lent as if they were physical units, meaning that they can only be lent to one user at a time, so libraries must purchase two licenses if they wish two have two copies of the same book. Moreover, once the books have been lent, other borrowers who wish to read them must reserve them, and once the books are eliminated from the borrower's device upon the expiration of the loan period, they are then transferred to the account of the users who have reserved them. 


\section{Conclusion}

The increasing popularity of e-books involves multiple changes in almost all aspects relating to the publishing industry and to consumer and reading habits, ranging from the transformation and definition of business models based on the proposals of publishing agents, the transformation of the production chain and changes in the marketing of book and pricing policies, as well as the redistribution of authors' revenues and issues related to safeguarding the rights of both parties. The library, as a managere and content provider, is not alien to this rebalancing, which affects various aspects relating to the management, development and design of services for the purpose of incorporating this new format. These transformations have implications affecting the relationship between publishers and libraries, as well as the internal organization and distribution of tasks assigned to staff members, the development and design of services, and the relationship between users and libraries. All of above aspects are paramount when designing budgets and defining improvements in economic management of the library, through the selection of the finest collections of e-books, allowing for improved use and an expansion of library users.

\section{References}

"EBook Lending Libraries." MobileRead Wiki (2009).

http://wiki.mobileread.com/wiki/EBook_Lending_Libraries

"Libros electrónicos de NetLibrary ${ }^{\mathrm{TM}}$ : Libros electrónicos de texto completo de NetLibrary". OCLC (2010). http://www.oclc.org/americalatina/es/ebooks/default.htm

Alonso Arévalo, Julio, José A. Cordón-García, y Helena Martín-Rodero. "The emergence of electronic books publishing in Spain”. Library Hi Tech (2010)

Alvite Díez, Luisa, y Blanca Rodríguez Bravo. "E-books in Spanish academic libraries". The Electronic Library, 27, 1 (2009): 86-95. http://ejournals.ebsco.com/direct.asp?ArticleID=406495E8F8610EED9F2B Anuradha, K. T., y H. S. Usha. "Implicationsof eBooks in libraries". Indian Institute of Science Bangalore (2010).

http://www.chillibreeze.com/articles_various/epublishing/16.\%20Implications\%20of\%20eBooks\%20in\% 20libraries.pdf

Barsky, Eugene, Lisa Schattman, y Aleteia Greenwood. "Comparing Safari Tech Books Online and Books24x7 E-book Collections: A Case Study from the University of British Columbia Library”. Issues in Science and Technology Librarianship, 56 (2009): 2. http://www.istl.org/09-winter/article2.html Beall, Jeffrey. "Free Books: Loading Brief MARC Records for Open-Access Books in an Academic Library Catalog”. Cataloging \& Classification Quarterly, 47, 5 (2009): 452-63. http://www.informaworld.com/10.1080/01639370902870215 Bennett, Linda, and Monica Landoni. "E-books in academic libraries", The Electronic Library, 23, 1 (2005). http://www.emeraldinsight.com/10.1108/02640470510582709 
Berube, L. "E-Books in Public Libraries: a Terminal or Termination Technology?". Interlending \& Document Supply, 33, 1 (2005). http://www.emeraldinsight.com/Insight/viewContainer.do?containerType=Journal\&containerId=10957 Brantley, Peter. "Digital Books and the Impact on Libraries". Library Trends, 57, 1 (2008): Monográfico. Chan, Elsie S. K., y Paula M. C. Wilkins Linda Swatman. "E-Book Technology and Its Impact on Libraries." CollECTeR'06 (2006).

http://www.collecter2006.unisa.edu.au/Paper\%207\%20Elsie\%20Chan.pdf Clavero, Javier, et al. "Estudio de caso de servicio de préstamo de libros electrónicos". El Profesional de la Información, 18, 2 (2009).

http://upcommons.upc.edu/e-prints/bitstream/2117/2846/1/clavero_estudiocaso.pdf Fernandes, Derrick. "The Safari e-book route through the ICT jungle: experiences at Hillingdon Libraries". Program: electronic library and information systems, 41, 3 (2007): 227-38. http://www.emeraldinsight.com/10.1108/00330330710774110 Gisbergen, Maxim van, Elyse Profera, y Christine M. Stamison. “A Librarian’s View of Ebook Acquisitions”. Infotoday.com (2010). http://www.infotoday.com/IT/dec09/vanGisbergen-ProferaStamison.shtml

Guy, Janssens, y Martin Harry. "The Feasibility of E-Ink Readers in Distance Learning: A Field Study". International Journal of Interactive Mobile Technologies (IJIM) (2009). http://online-journals.org/ijim/ article/view/726

Hernández Salazar, Patricia , David Nicholas, y Ian Rowland. “Acceso y uso de libros electrónicos por comunidades universitarias del Reino Unido Resumen PDF". Revista Interamericana de Bibliotecologia, 32, 2 (2009): 13-58. http://aprendeenlinea.udea.edu.co/revistas/index.php/RIB/article/view/5057/4417 Jamali, Hamid R., David Nicholas, y Ian Rowlands. "Scholarly e-books: the views of 16,000 academics: Results from the JISC National E-Book Observatory". Aslib Proceedings, 61, 1 (2009): 33-47. http://www.emeraldinsight.com/10.1108/00012530910932276 Joint, Nicholas. "The electronic book: a transformational library technology?". Library Review, 59, 2 (2010): 83-91. http://www.emeraldinsight.com/10.1108/00242531011023844

Jonchère, Laurent. "Des livres électroniques pour les étudiants: Une action de l'Université numérique en Région Bretagne". Bulletin des bibliothèques de France, 52, 6 (2007). http://bbf.enssib.fr/sdx/BBF/pdf/bbf-2007-6/bbf-2007-06-0028-005.pdf Kiriakova, Maria, et al. "Aiming at a Moving Target: Pilot Testing Ebook Readers in an Urban Academic Library". Computers in Libraries, 30, 2 (2010): 20-24.

http://search.ebscohost.com/login.aspx?direct=true $\& d b=1 x h \& A N=48757663 \&$ site=ehost-live Landoni, Monica, y Gillian Hanlon. "E-book reading groups: interacting with e-books in public libraries". The Electronic Library, 25, 5 (2007). http://www.emeraldinsight.com/10.1108/02640470710829578 Levine-Clark, Michael. "Electronic books and the humanities: a survey at the University of Denver". Collection Building, 26, 1 (2007): 7-14. http://www.emeraldinsight.com/10.1108/01604950710721548 Merlo Vega, José Antonio, y Angela Sorli Rojo. "Bibliotecas Digitales (I): colecciones de libros de acceso público". Revista española de documentación científica, 23, 1 (2000).

http://exlibris.usal.es/merlo/escritos/redcbd1.htm 
Nelson, Mark R. "E-Books in Higher Education: Nearing the End of the Era of Hype?". Educase review, 43, 2 (2008). http://net.educause.edu/ir/library/pdf/ERM0822.pdf

Nicholas, David, et al. "UK scholarly e-book usage: a landmark survey". Aslib Proceedings, 60, 4 (2008): 311-34. http://www.emeraldinsight.com/10.1108/00012530810887962

Park, Yeon-Hee. "A study of consortium models for e-books in university libraries in Korea”. Collection Building, 26, 3 (2007): 77-83. http://www.emeraldinsight.com/10.1108/01604950710761634

Parkes, David. "E-books from ebrary at Staffordshire University: a case study", Program: electronic library and information systems, 41, 3 (2007): 253-61.

http://www.emeraldinsight.com/10.1108/00330330710774138

Pérez Arranz, Fernando, y Purificación Moscoso. "El libro electrónico y su incidencia en las bibliotecas universitarias y científicas españolas". Revista Española de Documentación Científica, 30, 3 (2007). http://redc.revistas.csic.es/index.php/redc/issue/view/46 Perrone, Agnese. "Electronic Book Collection Development in Italy: a case study". IFLA Journal, 35, 4 (2009): 305-12. http://www.ifla.org/files/hq/papers/ifla75/212-perrone-en.pdf Renner, Rita A. "eBooks - Costs and Benefits to Academic and Research Libraries”. Springer.com (2009).

http://www.springer.com/cda/content/document/cda_downloaddocument/eBook+White+Paper.pdf?SGW $\mathrm{ID}=0-0-45-415198-0$

Rich, Motoko. "Los desafíos en el préstamo de libros digitales". The New York Times (2009). http://www.lanacion.com.ar/nota.asp?nota_id=1187212 Rodríguez Bravo, Blanca. "Evaluación del acceso y gestión de los libros electrónicos en las bibliotecas universitarias españolas". Feycit (2004). http://univ.micinn.fecyt.es/univ/html/informes/estudios_analisis/resultados_2004/ea0115/ea0115.pdf Shelburne, Wendy Allen. "E-book usage in an academic library: User attitudes and behaviours". Library Collections, Acquisitions, and Technical Services, 33, 2-3 (2009): 59-72. http://www.sciencedirect.com/science/article/B6VSH-4WJ91G91/2/3463459efdcd3410bcbef8885ef5e60e Simpson, Betsy, Jimmie Lundgren, y Tatiana Barr. "Linking Print and Electronic Books: One Approach". Library Resources \& Technical Services, 51, 2 (2007): 146-52.

Siriginidi Subba, Rao. "Electronic books: their integration into library and information centers". The Electronic Library, 23, 1 (2005).

http://www.emeraldinsight.com/Insight/viewContentItem.do?contentType=Article\&hdAction=lnkpdf\&co ntentId=1464899

Soules, Aline. "The shifting landscape of e-books". New Library World, 110, 1/2 (2009): 7-21. http://www.emeraldinsight.com/10.1108/03074800910928559 Steen, David. "EBooks From Institutional to Consortial Considerations". Online, 34, 3 (2010): 29-35. http://search.ebscohost.com/login.aspx?direct=true \&db=lxh\&AN=50140886\&site=ehost-live Taylor, Alison. "E-books from MyiLibrary at the University of Worcester: a case study". Program: electronic library and information systems, 41, 3 (2007): 217-26. http://www.emeraldinsight.com/10.1108/00330330710774101 Universidad Complutense de Madrid. "Normativa y formulario de solicitud de préstamo de lectores de 
libros electrónicos", Universidad Complutense de Madrid (2009).

http://www.ucm.es/BUCM/eis/doc11773.pdf

Van Gisbergen, Maxim, Elyse Profera, y Christine M. Stamison. “A Librarian's View of Ebook

Acquisitions". Information Today, 26, 11 (2009): 14-15.

http://search.ebscohost.com/login.aspx?direct=true\&db=lxh\&AN=45574463\&site=ehost-live

Vasileiou, Magdalini, Richard Hartley, y Jennifer Rowley. "An overview of the e-book marketplace".

Online Information Review, 33, 1 (2009): 173-92.

http://www.emeraldinsight.com/10.1108/14684520910944454

Wilkins, Valerie. "Managing e-books at the University of Derby: a case study". Program: electronic

library and information systems, 41, 3 (2007): 238-51.

http://www.emeraldinsight.com/10.1108/00330330710774129 